\title{
AANTEKENINGE OOR DIE WET OP HUURBEHUISING 50 VAN 1999
}

\section{SPLR de la Harpe}

Potchefstroom Universiteit vir Christelike Hoër Onderwys

\section{INLEIDING}

Artikel 26 van die Grondwet ${ }^{1}$ bepaal soos volg:

1) Elkeen het die reg op toegang tot geskikte behuising.

2) Die staat moet redelike wetgewende en ander maatreëls tref om binne sy beskikbare middele hierdie reg in toenemende mate te verwesenlik.

3) Sonder 'n hofbevel wat na oorweging van al die tersaaklike omstandighede toegestaan is, mag niemand uit hul woning gesit word en mag niemand se woning gesloop word nie. Geen wetgewing mag arbitrêre uitsettings veroorloof nie.

Op 9 Desember 1999 is die Wet op Huurbehuising, ${ }^{2}$ goedgekeur en op 1 Augustus 2000 het die wet in werking getree. Hierdie wet is 'n tipiese voorbeeld van maatreëls wat geskep is om, in samewerking met die privaatsektor, voorsiening te maak vir derde generasie fundamentele regte.

Die Wet op Huurbehuising het die Wet op Huurbeheer ${ }^{3}$ vervang. Laasgenoemde wet het hoofsaaklik ten doel gehad om, in die geval van gekontroleerde persele, huurgelde en die uitsetting van huurders te reël. Die Wet op Huurbehuising, datenteen, het ten doel om meganismes te skep om die voorsiening van huurbehuisingseiendom te bevorder, toegang tot voldoende huurbehuising te bevorder en huurbehuisingstribunale te skep wat goeie betrekkinge tussen huurders en verhuurders kan fasiliteer en konflikoplossing kan bewerkstellig. In die besonder kan die huurbehuisingstribunaal aspekte soos oorbewoning, onaanvaarbare woontoestande, uitbuitende huurgeld en gebrek aan instandhouding hanteer. ${ }^{4}$

Wet 108 van 1996. Hierna verwys as die Grondwet.

Wet 50 van 1999.

Wet 80 van 1976.

Artikel 13(1)(c). 
Alhoewel die Wet op Huurbehuising tot interessante grondwetlike aspekte aanleiding gee word in hierdie aantekening gekonsentreer op die invloed van die wet op kontraktuele aspekte, en in die besonder, die huurreg. Die woordbepalings soos vervat in Artikel 1 en Hoofstuk 3 van die wet is in die verband van belang en word vervolgens bespreek.

\section{WOORDBEPALINGS}

Dit is nodig om sekere opmerkings oor die woordomskrywing van enkele begrippe soos vervat in artikel 1 van die wet te maak.

\subsection{Huurkontrak}

Artikel 1 van die wet omskryf "huurkontrak" soos volg:

'n huurooreenkoms aangegaan tusen
verhuurder ten huurder en 'n
behuisingsdoeleindes........

Dit is belangrik om daarop te let dat alleen wonings wat vir behuisingsdoeleindes aangewend word onder hierdie woordomskrywing val. Wonings wat byvoorbeeld vir besigheids- of soortgelyke doeleindes aangewend word sal nie deur hierdie wet geraak word nie. Die eerste probleem wat voorsien word is dat dit dikwels gebeur dat 'n woning vir behuisings - en ander doeleindes gebruik word. Alhoewel artikel 26 handel oor die reg op behuising en die wet daarop gerig is om daardie reg te verwesenlik, is dit vir 'n groot deel van ons bevolking ' $n$ werklikheid dat ekonomiese aktiwiteite vanuit hul wonings bedryf word. Veral in die informele sektor gebeur dit dat die "makuka", 5 waarin die entrepeneur bly, grootendeels vir sy besigheid gebruik word. Dit sou meer gewens wees om ook aan hulle die beskerming van die wet te verleen. Die vraag ontstaan of behuising vir vakansiedoeleindes ook behuisingsdoeleindes is en gevolglik deur die bepalings van die wet geraak word. Dit was sekerlik nooit die doel van die

$5 \quad$ Tydelike kamertjie, gewoonlik van sink. 
wetgewer om vakansiebehuising in te sluit nie. Die huur van 'n kamer in 'n hotel sal moontlik onder hierdie woordomskrywing, gelees met die woordomskrywing "woning", val. Daar is natuurlik die onderskeid tussen 'n residensiële hotel, waar kamers vir maande of selfs jare gehuur word, en die gewone hotel wat nie in langtermyn verblyf spesialiseer nie. In eersgenoemde geval sal 'n mens eerder beskerming van huurders wil hê as in laasgenoemde geval. Die wye omskrywing van 'n huurkontrak kan in die praktyk probleme veroorsaak. Tog kan die werking van die wet beperk word deur "behuisingsdoeleindes" eng te interpreteer om byvoorbeeld nie kortstondige behuising vir vakansie-en besigheidsdoeleindes in te sluit nie.

\subsection{Woning}

'n "Woning" word soos volg omskryf:

....ook 'n huis, hotelkamer, hut, krot, woonstel, kamer, buitegebou, garage of soortgelyke struktuur wat gehuur word, asook 'n stoorkamer, buitegebou, garage of afgebakende parkeerruimte wat as deel van die huurkontrak gehuur word.

Die woordomskrywing van "woning" is uiters omvattend. Dit sal byvoorbeeld "makukas" en soortgelyke strukture in agterplase en informele nedersettings insluit.

\subsection{Onbillike praktyk}

'n "Onbillike praktyk" word in die wet omskryf as:

...'n praktyk voorgeskryf deur die LUR as 'n praktyk wat die regte of belange van ' $n$ huurder of verhuurder onredelik benadeel.

Hierdie bepaling moet met artikel 15(1)(f) saamgelees word, wat voorsiening maak vir die uitvaardiging van regulasies deur die LUR, asook met die woordomskrywing "voorgeskryf". 
Die feit dat daar nege LUR's is wat elk sy eie regulasies kan uitvaardig bring mee dat wat in een provinsie 'n onbillike praktyk is, nie noodwendig in 'n ander provinsie een is nie. Dit is natuurlik nie bevorderlik vir regsekerheid nie.

\section{BETREKKINGE TUSSEN HUURDERS EN VERHUURDERS (Hoofstuk 3 van die wet)}

Artikels 4 en 5 van die wet het sekere bepalings wat die verhouding tussen huurders en verhuurders reël en het 'n direkte invloed op die partye se kontrakteervryheid. Hierdie bepalings word vervolgens bespreek.

\subsection{Artikel 4}

Artikel 4(1) verbied onregverdige diskriminasie:

- by advertering van 'n woning vir doeleindes van die verhuring daarvan;

- tydens onderhandelinge met 'n voornemende huurder oor die huurkontrak; en

- gedurende die huurtermyn.

Onregverdige diskriminasie teen sodanige voornemende huurder, of huurder, of die lede van sodanige huurder se huishouding, of die bona fide besoekers van sodanige huurder word ook verbied.

Die gronde vir diskriminasie is een of meer van die volgende: op een of meer gronde insluitende ras, geslag, swangerskap, huwelikstaat, seksuele oriëntasie, etniese of maatskaplike oorsprong, kleur, ouderdom, ongeskiktheid, geloof, gewete, oortuiging, kultuur, taal en geboorte. ${ }^{6}$

Hierdie bepalings sal deeglik in ag geneem moet word by die verhuring van eiendom vir behuisingsdoeleindes. Interessante vrae ontstaan, byvoorbeeld of die advertering van eiendom in verskillende tale en koerante gedoen moet word en of koerante, wat hoofsaaklik deur sekere dele van die bevolking 
gelees word, altyd ingesluit moet word. Die eenvoudige antwoord is dat dit net nie onregverdige diskriminasie daar moet stel nie. Dit is moeiliker om meer spesifieke riglyne te gee en dit sal waarskynlik op 'n kasuïstiese wyse deur die howe ontwikkel word. Wat regverdige diskriminasie daarstel, sal van geval tot geval afhang.

Artikel 4(2) bepaal dat die huurder die reg op privaatheid gedurende die huurtydperk het en dat die verhuurder alleen op redelike wyse en na redelike kennisgewing aan die huurder sy of haar reg op inspeksie kan uitoefen.

Artikel 4(3) bepaal dat die huurder die volgende regte het, naamlik:

- dat sy of haar persoon of woning nie deursoek mag word nie;

- dat sy of haar eiendom nie deursoek mag word nie;

- dat daar nie op sy of haar besittings beslag gelê mag word nie, behalwe ingevolge die reg van algemene toepassing en deurdat ' $n$ hofbevel eers verkry is; en

- dat daar nie op die privaatheid van sy of haar kommunikasie inbreuk gemaak word nie. ${ }^{7}$

'n Vraag wat ontstaan is of die bepaling dat alleen op 'n huurder se besittings beslag gelê kan word indien aan sekere voorvereistes voldoen is, enige invloed op die verhuurder se stilswyende hipoteek oor die huurder se roerende eiendom op die huurperseel, vir die betaling van agterstallige huurgelde sal hê. Hierdie bepaling het klaarblyklik sy oorsprong in artikel 14(c) van die Grondwet wat die reg op privaatheid waarborg met insluiting van die reg dat daar nie op 'n persoon se besittings beslag gelê mag word nie. Die normale interpretasie ${ }^{8}$ van die woord "beslaglegging" sluit nie die regte, wat voortspruit uit die stilswyende hipoteek van die verhuurder, in nie. Die aard van die stilswyende hipoteek is verskillend van die van beslaglegging. Die stilswyende hipoteek moet ook eers perfekteer word voor die verhuurder enige saaklike reg verkry. Die stilswyende hipoteek impliseer nie dat die

7 Vergelyk artikel 14 van die 1996 Grondwet. 
verhuurder eie-rigting mag toepas nie en die nodige regsproses moet steeds gevolg word voordat beslaglegging verkry kan word. Dit kom dus voor dat die gemelde stilswyende hipoteek nie deur die bepalings van artikel 4(3) van die wet geaffekteer word nie.

Die Wet op Landdroshowe ${ }^{9}$ maak voorsiening vir 'n outomatiese huurinterdik ${ }^{10}$ en beslaglegging ${ }^{11}$ op die roerende eiendom van die huurder en hierdie remedies word die meeste in die praktyk in die landdroshof gebruik.

Artikel 4(4) verorden dat bogenoemde regte in 'n gelyke mate van toepassing is op die lede van die huurder se huishouding en bona fide besoekers van die huurder.

Uit 'n kontraktereg-oogpunt is dit interessant dat derdes, synde lede van die huurder se huishouding en bona fide besoekers, wat nie 'n party tot die ooreenkoms is nie, sekere regte verkry wat voortspruit uit die feit van huur. As gekyk word na die bewoording van artikel 4(3) teenoor artikel 4(4) kom dit voor dat die derdes in eie reg ingevolge die bepalings van die wet sal kan ageer en dat dit nie net beperk word tot die huurder nie.

Artikel 4(3) bepaal uitdruklik wat 'n huurder se regte in hierdie verband is en artikel 4(4) bepaal dat die regte in subartikel (3) in gelyke mate van toepassing is op die gemelde derdes. Versuim om aan artikel 4 te voldoen is ingevolge artikel 16 'n misdryf wat strafbaar met 'n boete en gevangenisstraf van hoogstens twee jaar is.

Artikel 4(5) maak voorsiening vir die regte van die verhuurder teenoor die huurder synde:

- tydige en gereelde betaling; min moontlik te wysig. Spoor and Fisher v Registrar of Patents 1961 SA 476 (A), Palvie v Motale Bus Service (Pty) Ltd 1993 SA 742 (A).

$9 \quad$ Wet 32 van 1944.

10 Artikel 31.

11 Artikel 32. 
- verhaal van onbetaalde gelde na verkryging van ' $n$ beslissing van die tribunaal of 'n bevel van 'n geregshof;

- beëindiging van die kontrak op gronde wat nie 'n onbillike praktyk daarstel nie en wat in die kontrak gespesifiseer is;

- ontvang van die eiendom in 'n goeie toestand (behoudens redelike slytasie) by beëindiging van die huurkontrak;

- terugneem van die eiendom na verkryging van ' $n$ hofbevel; en

- eis van vergoeding vir skade aan die eiendom aangerig deur die huurder, 'n lid van die huurder se huishouding of 'n besoeker van die huurder.

Dit is belangrik om daarop te let dat die gronde waarop 'n huurkontrak beëindig kan word nie 'n grond wat 'n onbillike praktyk daarstel insluit nie. Soos reeds vermeld bepaal die LUR van die betrokke provinsie wat ' $n$ onbillike praktyk is. Hierdie bepaling kan potensieel ' $n$ groot invloed op ' $n$ verhuurder se normale kontraktuele remedies hê. By die opstel van ' $n$ huurkontrak sal die relevante regulasies telkens in ag geneem moet word. Die sukses van die wet gaan ook grootliks afhang van die omskrywing van ' $n$ onbillike praktyk deur die LUR's.

'n Verdere interessante ontwikkeling is dat die Hoogste Hof van Appél bevind het dat die Wet op die Voorkoming van Onwettige Uitsetting en Onregmatige Besetting van Grond $^{12}$ van toepassing is op gevalle waar ' $n$ voormalige huurder, vir behuisingsdoeleindes, na verstryking van die huurkontrak onregmatig op die huurperseel aanbly. ${ }^{13}$ Die verhuurder sal aan die bepalings van artikel 4 van die gemelde wet moet voldoen voor ' $n$ uitsettingsbevel verkry kan word. Hierdie aspek sal waarskynlik 'n belangrike oorweging vir sakelui wees by die beskikbaarstelling van huurbehuising, veral in die geval van goedkooop huurbehuising, aangesien faktore soos die regte en behoeftes van bejaardes, kinders, gestremdes en gevalle waar ' $n$ vrou die hoof van die huishouding is, deur die hof in ag geneem moet word voor ' $n$

12 Wet 19 van 1998.

13 Ndlovu v Ngcobo en Bekker en Bosch v Jika (saaknommers 240/2001 en 136/2002), tans nog ongerapporteer. Die uitspraak is gelewer op 30 Augustus 2002. 
uitsettingsbevel verleen word. ${ }^{14}$ Die effek hiervan mag wees dat die bepalings van die gemelde aartikel 4 teenproduktief vir die verskaffing van goedkoop huurbehuising mag wees aangesien daar 'n groter risiko bestaan dat die howe in die geval van behoeftige persone en die persone in hierdie artikel genoem nie 'n uitsettingsbevel sal verleen nie ten spyte van die feit dat die huurooreenkoms beëindig is.

\section{$3.2 \quad$ Artikel 5}

Hierdie artikel se bepalings is spesifiek gerig op die huurkontrak self. In artikel 5(1) word die gemeenregtelike posisie bevestig dat 'n huurkontrak nie op skrif hoef te wees nie, behoudens die bepalings van die Wet op die Formaliteite met betrekking tot Huurkontrakte van Grond. ${ }^{15}$ Hierdie wet het sekere bepalings ten aansien van die opskrifstelling van huurkontrakte vir 'n tydperk van 10 jaar en langer.

Artikel 5(2) bepaal dat indien die huurder dit versoek die verhuurder die ooreenkoms op skrif moet stel. Die volgende moet hierby in gedagte gehou word:

- Geen beperking word gestel op wanneer opskrifstelling versoek mag word nie en dit sal enige tyd tydens die duur van die kontrak kan geskied. By afloop van die kontrak is die partye, met inagneming van die woordomskrywing van huurder en verhuurder, nie meer huurder en verhuurder nie en die voormalige huurder gevolglik nie meer geregtig om die bepalings van artikel 5(2) af te dwing nie. Dit sal gevolglik vir enige huurder wys wees om 'n afskrif te versoek voor afloop van die kontrak.

- Die kontrak, indien mondeling of stilswyend, kom ingevolge die artikel reeds tot stand voor die versoek om opskrifstelling. Die regte en verpligtinge van die partye word gereël deur die oorspronklike mondelinge ooreenkoms en nie deur die latere skriftelike dokument nie. Die huurder moet daarom seker maak dat die skriftelike dokument, soos deur die verhuurder opgestel, 'n korrekte weerspieëling van die mondelinge

14 Artikel 4 (6) van 1998. 
ooreenkoms is. Die wesenlike gevaar bestaan dat 'n verhuurder, sodra versoek word om die kontrak op skrif te stel, òf 'n standaard kontrak gebruik òf 'n kontrak laat opstel wat voorwaardes bevat wat glad nie in die oorspronklike ooreenkoms vervat is nie. Indien so 'n huurder nie kapsie maak teen die skriftelike dokument nie kan hy mettertyd probleme ondervind om hom op die oorspronklike kontrak te beroep vanweë die werking van estoppel of vanweë bewysprobleme. Waar hierdie subartikel klaarblyklik ingevoeg is om sekerheid oor die bepalings van die ooreenkoms te bewerkstellig, kan dit moontlik in die praktyk onbillik werk teen 'n oningeligte huurder.

- 'n Verdere probleem is dat daar nie aangedui word wie vir die koste van die opskrifstelling verantwoordelik is nie. Die koste van opskrifstelling mag die partye ook afskrik om van die artikel gebruik te maak.

- Verder maak artikel 5(6) daarvoor voorsiening dat sekere inligting ingesluit moet word in die skriftelike kontrak vermeld in artikel 5(2). Hierdie bepaling mag 'n probleem skep in 'n geval waar die partye nie spesifiek op 'n aspek vermeld in artikel 5(6) ooreengekom het nie. Die korrekte posisie is myns insiens dat die naturalia moet geld indien 'n spesifieke ooreenkoms nie oor die aspek bereik is nie en sodanige naturalia in die skriftelike dokument vervat moet word. Daar moet natuurlik gekyk word of die partye nie stilswyend 'n ooreenkoms oor die aspekte bereik het nie.

Artikel 5(3) is interessant in dié sin dat dit bepaal dat dit geag word dat sekere bepalings, wat in 'n hof afdwingbaar is, in die huurkontrak ingesluit is. Die effek hiervan is dat die partye hul kontraktuele remedies moet gebruik om hulle regte, waarvoor in die artikel voorsiening gemaak word, af te dwing. Dit sal insluit die exceptio non adimpleti contractus, spesifieke nakoming en 'n eis vir skadevergoeding. Die kontrak sal alleen gekanselleer kan word indien die kontrakbreuk wesenlik is. Die probleem van 'n eis om spesifieke nakoming is dat 'n Landdroshof net jurisdiksie het om 'n eis om spesifieke nakoming te bereg indien daar in die alternatief ' $n$ eis vir skadevergoeding is. ${ }^{16}$ Die tribunaal wat deur die wet ingestel is kan alleen geskille betreffende ' $n$

15 Wet 18 van 1969. 
onbillike praktyk bereg en het nie jurisdiksie om alle geskille in verband met ' $n$ huurkontrak te bereg nie.

Die bepalings wat ingevolge hierdie artikel geag word ingesluit te wees het net op vier hoofaspekte betrekking:

- die voorsiening van kwitansies en inligting wat daarop moet verskyn; ${ }^{17}$

- die betaling van 'n deposito, die belê daarvan, betaling van rente daarop, die aanwending van die deposito en opgeloopte rente by verstryking van die huurkontrak en die terugbetaling daarvan aan die huurder; ${ }^{18}$

- inspeksie van die woning voordat die huurder intrek en by verstryking van die huurkontrak; ${ }^{19}$ en

- indien die huurder die woning voor die verstryking van die huurkontrak, sonder kennisgewing aan die verhuurder, ontruim, word die huurkontrak geag te verstryk op die datum waarop die verhuurder vasgestel het die huurder die woning ontruim het. ${ }^{20}$

Enkele probleme wat uit artikel 5(3)(c) voortspruit is die volgende:

- Die artikel bepaal dat die verhuurder kan vereis dat 'n huurder, voordat daar in die woning ingetrek word, 'n deposito betaal. Alhoewel hierdie 'n voorwaarde is wat geag word deel van die kontrak te wees, laat dit steeds die keuse aan die verhuurder om 'n deposito te vereis al dan nie. Die verhuurder het in elk geval gemeenregtelik hierdie keuse en dit maak nie werklik sin om dit in te voeg nie.

- Hierdie subartikel is verder onduidelik deurdat dit bepaal dat vereis kan word dat 'n huurder, voordat in die woning ingetrek word, 'n deposito betaal wat op daardie tydstip nie 'n bedrag mag oorskry wat gelykstaande is aan 'n bedrag in die ooreenkoms gespesifiseer of andersins tussen die partye ooreengekom:

- Dit is nie duidelik wat bedoel word met die bedrag in die ooreenkoms gespesifiseer nie. As die bedrag as deposito gespesifiseer is, is hierdie 
bepaling oorbodig.

- Die frase "of andersins tussen die partye ooreengekom" is ook onnodig, aangesien die partye nog altyd gemeenregtelik op 'n bedrag kon ooreenkom.

Artikel 5(3)(d) maak voorsiening vir die belê van die deposito by ' $n$ finansiële instelling en betaling van rente aan die huurder. Dit word nie duidelik uitgespel of rente op rente aan die huurder betaal moet word nie, wat veral relevant kan wees by ' $n$ huur vir 'n lang tydperk of van groot omvang. Die huurder behoort geregtig te wees op die rente op rente, aangesien dit nie deel van die huurbedrag vorm nie en aangesien rente, onderhewig aan sekere toelaatbare aftrekkings, eers by die verstryking van die huur terugbetaal hoef te word.

Art 5(4) bepaal dat daar nie afstand gedoen mag word van die standaard bepalings in subartikel (3) nie.

Wat artikel 5(3) (o) betref ontstaan die vraag op welke remedies die verhuurder geregtig is indien die kontrak ingevolge hierdie artikel verstryk het. In die besonder ontstaan die vraag of die verhuurder geregtig is op die normale kontraktuele remedies, onder andere die betaling van agterstallige huur en op betaling van die huur vir die onverstreke gedeelte van die huurkontrak. Daar kan nie veel twyfel wees dat die verhuurder steeds geregtig is op betaling van die agterstallige huur nie. Wat die eis vir toekomstige huur betref is ek van mening dat die betrokke artikel van die wet nie enige invloed behoort te hê op die verhuurder se gewone kontraktuele remedies in die verband nie. Die doel van die bepaling is waarskynlik nie om enige gemeenregtelike regte van die verhuurder weg te neem nie maar eerder om sekerheid te verskaf oor die datum van beëindiging van die huurkontrak. Die verhuurder sal onder die omstandighede onmiddellik ander huurders kan kry en sal ook nie die huurder in mora hoef te plaas nie. Die onregmatige beëididing van ' $n$ huurkontrak impliseer nie dat alle regte en verpligtinge voortspruitend uit die ooreenkoms ook beëindig word nie. 
Artikel 5(4) bepaal dat daar nie afstand gedoen mag word van die standaardbepalings in subartikel (3) nie.

Artikel 5(5) bepaal dat indien die huurder, by verstryking van die huurkontrak, met die uitdruklike of stilswyende toestemming van die verhuurder in die woning aanbly, die partye in die afwesigheid van 'n verdere skriftelike huurkontrak, geag word 'n periodieke huurkontrak aan te gegaan het, op dieselfde bedinge en voorwaardes as die verstreke huurkontrak, behalwe dat enigeen van die partye minstens een maand skriftelike kennis moet gee van die voorneme om die huurkontrak te beëindig.

Aangesien dit gereeld gebeur dat 'n huurder na afloop van 'n huurkontrak in die woning aanbly sal hierdie bepaling regsekerheid bevorder. In die lig van die beskerming wat hierdie wet self ten aansien van die opskrifstelling van mondelingse huurooreenkomste verleen, was dit onnodig om te vereis dat daar 'n skriftelike kontrak moet wees voor die artikel nie in werking tree nie. 'n Uitdruklike mondelinge ooreenkoms behoort voldoende te wees.

Artikel 5(6) bepaal welke inligting in die huurkontrak bedoel in artikel 5(2) ingesluit moet word. Artikel $5(6)(\mathrm{g})$ bepaal dat die verpligtinge van die huurder en verhuurder, wat nie afbreuk mag doen aan die bepalings van subartikel (3) of die regulasies betreffende onbillike praktyke nie, deel moet vorm van die kontrak. Hier word sekerlik net verwys na die verpligtinge pertinent op ooreengekom. Dit sal onrealisties wees om te dink dat leke al die naturalia van die huurooreenkoms sal ken en dit in die gemelde dokument sal vervat. Die naturalia behoort steeds die regte en verpligtinge van die partye te beheers indien die ooreenkoms daaroor swyg. Voorbeelde hiervan is die reg op vergoeding vir verbeterings, die retensiereg van die huurder, die verhuurder se stilswyende hipoteek vir onbetaalde huur, die "huur gaat voor koop" beginsel en soortgelyke regte en verpligtinge.

Soos reeds hierbo gemeld is ek van mening dat die stilswyende hipoteek vir onbetaalde huur nie geaffekteer word deur die bepalings van artikel 4(3) van die wet nie. Daar word aan die hand gedoen dat, tensy die wet uitdruklik 
anders bepaal, die naturalia onveranderd aanwending moet vind, eerstens vir doeleindes van regsekerheid en tweedens omdat hierdie bepalings in wese billik is en reeds die toets van die tyd deurstaan het.

\section{HUURBEHUISINGSTRIBUNAAL}

Hoofstuk 4 van die wet maak voorsiening vir die instel van huurbehuisingstribunale vir elke provinsie. Die tribunaal moet die pligte verrig en die oogmerke nastreef in hierdie hoofstuk uiteengesit. Die tribunaaal is ' $n$ kwasi-judisiële liggaam wat onder andere klagtes oor onbillike praktyke moet aanhoor. Daar word ongelukkig nie voorsiening gemaak dat 'n regsgeleerde deel moet vorm van die tribunaal wanneer klagtes oor onbillike praktyke aangehoor word nie. ' $n$ Beslissing van die tribunaal sal aan hersiening deur die Hooggeregshof onderhewig wees. ${ }^{21}$

\section{JURISDIKSIE}

Artikel 13(10) bepaal dat in die geval van dringendheid ' $n$ bevoegde hof genader kan word indien 'n persoon in staat was om dit te doen as dit nie vir hierdie wet was nie, of om, in die afwesigheid van 'n geskil betreffende 'n onbillike praktyk, verrigtinge in te stel vir die normale verhaling van agterstallige huurgeld of uitsetting. Die vraag ontstaan onmiddellik wat die posisie met betrekking tot ander regshulp wat nie hier na verwys word nie is, byvoorbeeld ' $\mathrm{n}$ bevel vir spesifieke nakoming. Aangesien jurisdiksie wat sodanige ander regshulp betref nie uitdruklik uitgesluit word nie, word aan die hand gedoen dat die howe se jurisdiksie net beperk word soos in artikel 13(9) uiteengesit. Dit is net 'n geskil betreffende 'n onbillike praktyk wat volgens hierdie artikel deur die tribunaal beslis moet word. Artikel 13(11) bepaal op sy beurt weer dat die Landdroshof te enige tyd, indien verrigtinge verband hou met 'n geskil betreffende 'n onbillike praktyk, sodanige aangeleentheid na die tribunaal kan verwys. Vanweë die woord "kan" word die indruk geskep dat die landdros 'n diskresie het en daarom wel jurisdiksie het om ook 
aangeleenthede rakende onbillike praktyke te bereg.

\section{TEN SLOTTE}

Hierdie wet is 'n welkome vervanging van die Wet op Huurbeheer. ${ }^{22}$ Veral die feit dat die beskikbaarheid van huurbehuising en onbillike praktyke in die wet hanteer word is te verwelkom. Verder maak die wet dit vir belanghebbendes moontlik om geskille oor onbillike huurpraktyke op 'n goedkoop en vinnige manier by te lê.

Tog is daar sekere praktiese probleme wat die effektiwiteit van die wet kan kortwiek. Dit is te betwyfel of die nodige infrastruktuur en opgeleide mannekrag aanvanklik vir die doeltreffende funksionering daarvan beskikbaar gaan wees. Die persone in die informele huursektor het die beskerming van die wet die meeste nodig, maar dit is reeds daar waar, vanweë die omvang van die probleme en die hoeveelheid mense betrokke, die wet moeilik geadministreer en toegepas kan word. Min huurders in die informele huursektor sal van hul regte bewus wees en dikwels is die omvang van die tekort in huurbehuising van so 'n aard dat benadeelde huurders eerder die onbillike toestande verduur as om klagtes te gaan lê wat tot gevolg mag hê dat hulle hulle blyplek verloor. 